\title{
The Emerge of Students Engagement in Speaking Class
}

\author{
Sophia Binnendyk \\ Faculty of Teacher Training and Education, Pattimura University, Poka, Ambon - Indonesia
}

The research is supported by Directorate General of Higher Education Ministry of Research, Technology and Higher Education of Republic of Indonesia the organizer of BPPDN

\begin{abstract}
This recent study is conducted by aim to identify students' engagement. The students' particular engagements were gained in the speaking class. The engagement were focus on the students' emotional, behavior, and cognitive.

Qualitative approach was chosen as the research design and the study case covered the research method. It was conducted in 2 different high schools in Ambon. Observation sheet was applied to gain data for observing the speaking class and interview was used to gather data of the students' engagement.

This result of this study analysis reveals that students engagement were emerge among the students on those 2 schools were varied. Not all students had all engagement elements but it was proven that all students had different engagement and speaking practice skill.
\end{abstract}

Keywords: Speaking practice, engagement, cognitive, emotional, behavior

DOI: $10.7176 / \mathrm{JEP} / 11-21-14$

Publication date:July $31^{\text {st }} 2020$

\section{Introduction}

Productive engagement is an important means by which students develop feelings about their peers, professors, and institutions that give them a sense of connectedness, affiliation, and belonging, while simultaneously offering rich opportunities for learning and development. Bensimon (2009, xxii-xxiii) in Vicky (2010).

In building meaningful communication, speaking is generally considered as one of the major productive. As clarified by Brown (2001: p.140), "Speaking is a productive skill that can be directly and empirically observed". In emphasizing the objectives of teaching speaking to students, Brown and Yule (2010) inform that the purpose of speaking course is the students are able to express themselves in the target language; to conduct the basic interactive skill, such as exchanging greetings, saying thanks, and apologies; and express their need, request information, giving service and etc. Ironically, there are millions students who are not able to communicate by using English (Mattarima \& Hamdan, 2011: p.287). This point of view supported by Thalal (2010) who stated that the reality shows most students do not meet the expectation of their English proficiency, because their capability still need improvement or no significant progress of English ability after years studying the language.

Student engagement is generally considered to be among the better predictors of learning and personal development. The premise is deceptively simple, perhaps self-evident. The more students study or practice a subject, the more they tend to learn about it. Likewise, the more students practice and get feedback on their writing, analyzing, or problem solving, the more adept they should become (Kuh, 2003).

Depend on strategies merely without any considering to students' engagement means no evaluation to students' outcomes. In fact, engagement has correlation to the students' achievement in learning process (Trawler, 2010: p.3). In the teaching process, engagement requires students to not only being active in classroom interaction but also their feeling and sense of making all of their activities should be interacted in order to gain the soul of learning and attain the objective of learning.

In focusing on engagement at a school level, Fredricks, Blumenfeld and Paris (2004: P.62-63), identify three components of student engagement, discussed as follows; 1) Behavioral Engagement, 2) Emotional Engagement, 
3) Cognitive Engagement. By working along together of teaching strategies in aimed to students' engagement, optimistically teaching learning process will gain the objective of learning thus it results great outcomes.

Based on the elucidation above, the objective of this study are:

1. The study is willing to elaborate the students speaking skills;

2. To identify the emerge of students engagement in the speaking class. These objectives lead this study to find the answer detail and accurately.

\section{Literature Review}

\subsection{Teaching Speaking}

The purpose of the teaching spoken language is to develop student's ability in interacting success of the language and involving comprehension as well as production. Riggernbargh and Lazaratton (1991) claims that students will be considered successful if they are able to communicate effectively in the language. Thornburry (1994: p.28) proposes teachers to give students opportunities to practice the target language fully as it is important for contributing failure in the process of practicing the speaking in the class.

In line with the elucidation above, Ur (1996: p.120) and Brown 1987: 406-407) who have same idea about successful teaching speaking skill stated that there are some characteristics common in successful speaking tasks:

\subsubsection{Learners Talk a Lot}

It means that teachers ought to design speaking activities by aim to enhance the students to speak out in English. Van Geert (1995) in Cameron (2005: p.21), believe that speaking skill in foreign language grows better through classroom tasks and activities as he said those as the environment or ecosystem.

\subsubsection{Limit the Use of Native Language in the Class}

One common problem in speaking activities in the classroom is the teacher talks too much of the time. In gaining successful speaking tasks, students should talk a lot in the foreign language as much as possible at the period of time assigned to the activity. This influences students to often produce one or two simple utterances in the foreign language and spend their time chatting in their language. Thornburry (1994: p.28) proposes teachers to give students opportunities to practice the target language fully as it is important for contributing failure in the process of practicing the speaking in the class. One common problem in speaking activities in the classroom is the teacher talks too much of the time. In gaining successful speaking tasks, students should talk a lot in the foreign language as much as possible at the period of time assigned to the activity. This influences students to often produce one or two simple utterances in the foreign language and spend their time chatting in their language. Thornburry (1994: p.28) proposes teachers to give students opportunities to practice the target language fully as it is important for contributing failure in the process of practicing the speaking in the class. One common problem in speaking activities in the classroom is the teacher talks too much of the time. In gaining successful speaking tasks, students should talk a lot in the foreign language as much as possible at the period of time assigned to the activity. This influences students to often produce one or two simple utterances in the foreign language and spend their time chatting in their language. Thornburry (1994: p.28) proposes teachers to give students opportunities to practice the target language fully as it is important for contributing failure in the process of practicing the speaking in the class.

\subsubsection{All Students Have Same Opportunities to Speak Up in the Class}

In all participation, whether the task for whole class or in small group, successful task means encourage students to conduct conversation as possible. The task should be designed purposefully so that the oral output of particular students do not dominate discussions but all students have a chance to speak, and contributions fairly.

\subsubsection{High Motivation}

Students will be at ease to speak, when there is a clear objective that must be reached and of course when the topic is interesting for them. Again great attention should be taken to ensure the task is in line with the students and to avoid them to may think it is childish and thus lose interest in involving. Brown (2007: p.168) claims that "motivation is a star player in the cast of characters assigned to second language learning scenarios around the world". 


\subsubsection{Right Language Level}

Good designed task can stimulate students to complete the task successfully with the language that they have. Students can express themselves in producing relevant and comprehensible utterances and of an acceptable level of language accuracy. The students will be likely to give up or revert back to the native language if they are lack too much vocabulary so that the task will be come frustrating.

Nunan(1991) emphasized a measurement of successin language learning is interms of the ability to produce a conversation in the target language. Harmer (1998: p.52) explained that there are fourthings that students need to do with a new language: a). be exposed to it, b) understand its meaning. c) understand its form (how it is constructed) and the last c) is practice it. English in Indonesia is as foreign language, that is why EFL students need lots of exposures since they are much less exposed to target language. Moreover, Krashen (1982) added idea about the goal of the EFL classroom is to bring students in applying the target language to the place where they can use the out side world for furtherac quisition. Still teachers should prepare EFL students for further learning as independent learners in an English-speaking environment even they are possible to bring the out side world in to the class room setting. Last, those successful indicators will be difficult to approve if teachers do not have good and proper strategies to teach speaking.

Meanwhile, Harmer (2007:271) suggests that there are six effective speaking activities students can do to improve their speaking skills. Those speaking activities are as follows:

1)Acting from a script. Students can be asked to act out scenes from plays in the classroom and sometimes make a video recording of the performance. It will encourage students to frequently perform in front of the class. The teacher has to give students time to rehearse the dialogues before they are asked to perform. When all students are practicing, the teacher can give attention to their intonation, stress, and speed. By giving students the practice before their final performance, as the result, acting out is both learning and a language producing activity.

2) Communication Games. Games are very effective to encourage many learners to make their interests and work sustainable. Games also help the teacher to create contexts in which the language is useful and meaningful. For instance, pictures games which are designed to provoke communication between students usually depend on an information gap so that one student has to talk to a partner in order to solve a puzzle, draw a picture (describe and draw), put things in the right order (describe and arrange) or find similarities and differences between pictures.

3) Discussions. The difficulties of having discussion are that the students are shy and reluctant to share their opinion in front of the whole class and are not confident of the language they used to express their ideas. To avoid these difficulties, teachers can set up different types of discussion namely buzz groups, instant commentingactivities, and formal debates. Buzz groups give students a chance for quick discussions in small groups before any of them are asked to speak in front of the class or public. Meanwhile, instant comment mini-activities can train students to respond fluently and immediately. This activity involves showing students photographs or introducing topics and nominating them to say the first thing that comes to their mind. In formal debates, students prepare their arguments or against various propositions. When the debate starts, the speakers produce well-rehearsed arguments whereas others as the audience pitch in with their own thoughts which are less scripted on the subject or topic as the debate progresses.

4) Prepared Talks. Another activity to perform speaking is prepared talks where a student (or students) makes a presentation based on a certain topic. Because they are prepared, students should speak from notes rather than from a script to avoid these activities being more writing-like.

5) Questionnaires. Questionnaires ensure that both questioner and respondent have something to say to each other so that it is very useful to make students speak. Students can design questionnaires on any appropriate topic they are interested. Teacher can act as a resource and help students in designing it. The results can form the basis for discussions or prepared talks.

6) Simulation and Role play. Simulation and role play stimulate a real-life encounter and can be used to encourage general oral fluency. Students take on the role of a character different from themselves or with thought and feelings they do not necessarily share. 


\subsubsection{Students Engagement}

Kuh. (2007) defined student engagement, as students are active to participate inside as well as outside classroom activities, which hints to a range of measurable outcomes.

Meanwhile, Krause and Coates, (2008: p.493) also Hu and Kuh (2001: p.3) clarify the objectives of engagement is to achieve students learning outcomes by devoting their time and effort to do the activities that contribute directly. Trowller (2010: p.3) affirms student engagement with active participation done by the students through their time in the classroom. Both students and their institutions ought to participate the students' interaction between the time, effort, and other relevant resources. It intended to expand students' experience and enhance their learning outcomes.

In the teaching process, engagement requires students to not only being active in classroom interaction but also their feeling and the sense of making all of their activities should be interacted in order to gain the soul of learning and objective of learning. Stoval (2003) argue that students engagement create students to be more enthusiasm, wishes, desires motivation and success in the learning process also their willingness to take a part in teaching activities in the classroom.

\subsubsection{Engagement Component}

Harper \& Quaya (2009: p. 5) emphasizes engagement is more than participation or involvement. Engagement entails sense and feelings of the students in conducting activities in learning process. Students' acting out without feelingengaged is just involvement or even obedience; feeling engaged without acting is just separation. It means that students who participate actively in the class usually include their psychology factor, so that all the activities can run well without any pressure from the teachers.

In focusing on engagement at a school level, Fredricks, Blumenfeld \& Paris (2004:p. 62-63), identify three components of learner engagement, discussed as follows; 1) Behavioral Engagement, 2) Emotional Engagement, 3) Cognitive Engagement. The first component of engagement is Behavioral Engagement. Three main classifications of behavioral engagement are positive responds, involvement in learning, and participation in activities (Fredericks, Blumenfeld \& Paris: 2004).

Table 2.1 Students Engagement

Modified from Trowller (2010) and Fredrict, Blumfield, and Paris, (2003)

\begin{tabular}{|c|c|c|}
\hline & \multicolumn{2}{|c|}{ STUDENTS ENGAGEMENT } \\
\hline & Indicators & Sub-indicators \\
\hline \multirow{3}{*}{ Cognitive } & Comprehension & $\begin{array}{l}\text { students can response the teachers' } \\
\text { questions and do the classroom activities }\end{array}$ \\
\hline & Share ideas & $\begin{array}{l}\text { Students can communicate their ideas to } \\
\text { the classroom and help each other to do the } \\
\text { tasks. }\end{array}$ \\
\hline & $\begin{array}{l}\text { Preview } \\
\text { knowledge }\end{array}$ & $\begin{array}{l}\text { Answer the teachers questions related to } \\
\text { the last materials }\end{array}$ \\
\hline \multirow[t]{2}{*}{ Emotional } & Interest & $\begin{array}{l}\text { The students want to join to class and do } \\
\text { the classroom activities }\end{array}$ \\
\hline & Worried & Afraid to make mistake and keep silent \\
\hline \multirow{4}{*}{ Behavioral } & Attention & $\begin{array}{l}\text { The students fallow and do the teachers } \\
\text { instruction }\end{array}$ \\
\hline & Effort & $\begin{array}{l}\text { The students do the tasks in or out of the } \\
\text { classroom and submit on time }\end{array}$ \\
\hline & $\begin{array}{l}\text { Classroom } \\
\text { Participation }\end{array}$ & $\begin{array}{l}\text { The students participate actively and do the } \\
\text { classroom activities }\end{array}$ \\
\hline & $\begin{array}{l}\text { On time to follow } \\
\text { the Lesson }\end{array}$ & $\begin{array}{l}\text { The students have the responsibility and on } \\
\text { time to follow the lesson. }\end{array}$ \\
\hline
\end{tabular}

The objective of instruction for the behaviorists is to provoke the desired response from the students who is presented with a target stimulus. To accomplish this, the students must recognize how to perform the appropriate response as well as the condition in which that response should be delivered, Eagerly, significantly impact to 
students' achievement as good outcomes in their learning process will be achieved by stimulating students' engagement. The evidence for the role of engagement in influencing academic outcomes such as achievement and learning have provided by many former studies. Achievement is usually assessed through grades on exams and standardized achievement tests and it is defined as an indicator of individuals' academic ability (Handelsman, Briggs, Sullivan, \&Towler, 2005; Skinner et al., 2008; Skinner et al., 1990).

\section{Research Method}

This study employs a qualitative case study as the research design. In relation with the revelation above, Coffey $\&$ Delamont (2001: 7) and Dornyei (2007: 38) revealed that qualitative approach is to explore the behavior, perspectives, feelings and experiences of people and what lies at the core of their lives. Besides, this study observed students response about the teachers strategies implemented in the classroom. This study concern on the students speaking class activities and the students engagement. It means that, this study sought to understand the phenomena, experience and response of particular condition or case. According to Sturman (1997: 61), a case study is a general term for the exploration of an individual, group or phenomenon. It describes the phenomena occurred between teachers and students in the classroom.

The subject and setting of this study occurred on 2 high schools in Ambon, and it took places in 2 different class of those school. Each class consist of 25 students of high school in grade X.

In line with Dornyei (2007: p.37-38), based on the qualitative approach used in this study, the data was classified into three techniques. They are written document (lesson plan, detail result of observation, result of interview), spoken utterances (language used by teachers and students in the classroom) as well as their cognitive, behavioral and emotional engagement when they produced the utterances. To sustain those both data, image (photo and video) is needed through recording the process of teaching and learning process.

Two techniques of instruments utilized to collect data in this study were observation. To gain data of the first research question, the instrument used was observation sheet, while guide was applied to gather data for the second research question about the students' engagement. Observation (checklist and sheet or field note), (to the students), document images (photo and video).

Within the observation, speaking class activities are stated as follows. There are 2 topics taught to the students and those teachers have different way in teaching the students with different activities applied in the classroom. The following is the data of instrument in gathering data for students' engagement.

Table 3.1 Students Engagement Modified from Trowller (2010) and Fredrict, Blumfield, and Paris, (2003)

\section{STUDENTS ENGAGEMENT}

Indicators

Comprehension

Cognitive

Preview knowledge

Interest

Emotional

Worried

Attention

Effort

Behavioral

\section{Sub-indicators}

students can response the teachers' questions and do the classroom activities

Students can communicate their ideas to the classroom and help each other to do the tasks.

Answer the teachers questions related to the last materials

The students want to join to class and do the classroom activities

Afraid to make mistake and keep silent

The students fallow and do the teachers instruction

The students do the tasks in or out of the classroom and submit on time

Classroom

Participation

The students participate actively and do the classroom activities

On time to follow the The students have the responsibility and on time to Lesson follow the lesson. 
The step of collecting data can be seen in the following graphic. The procedure graphic led observer to observe and analyze data, thus they can understand the flow of the data collection technique.

Graphic 3.1 Procedure of Data Collection Technique

Adapted from Daniel Johnie, Qualitative Research Design (2013)

Procedure of
Data Collection
Techniques

Procedure of

Techniques

\section{Preliminary Research}
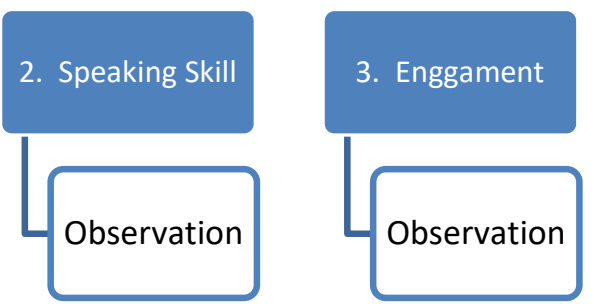

The detailed procedures to collect the data are described below:

1. Preliminary Research; the observer went to the school to gain preliminary data and observe the schools and the students.

2. The observer conducted an observation and noted on the observation sheet to all phenomenon in the speaking class.

3. The observer gathered data of students' engagement through observation the students in both classes of the schools.

\subsection{Findings}

The findings of the research to be cleared and detail in explanation will be elaborated based on the research question.

\subsubsection{Student's speaking skills}

Students speaking skills are observed through some components; Pronunciation, grammar, vocabulary, and fluency, and comprehension. Based on Brown (those components are the main points to know one's speaking skill. It can be seen in the rubric on chapter 3 table 3.9. But in this study the rubric was modified according to students' context and students' need. Two aspects did not appear in this study were Pronunciation, and comprehension. There are two reasons that can be said related to that, include pronunciation and comprehension. First, there are the diversities of the people in the world to use their own style in pronouncing the target language, it will be difficult to decide which one is appropriate pronunciation and which one is not appropriate pronunciation. Second, comprehension aspect have been covered in the four basic skills simultaneously when the people can interact verbally on non-verbally in their daily life. It means that when people can interact verbally or non-verbally they have well comprehension.

\subsubsection{Grammar}

Grammar is one of the important component of speaking, so in the teaching learning process of speaking, teachers focus more on grammar. It is based on the fact that students' grammar were still low. Their grammar is their frequently committed errors which showed some major uncontrolled pattern and causing occasional irritation and misunderstanding. In the teaching learning process, when the students practiced speaking with the teacher, their pair, or in front of the class, it can be seen the product of their grammar in conversation. Some of the students often made errors in producing the sentence grammatically. Teacher did not direct to correct the student's errors, but she asked the class opinion to restore their friends mistake. It can be seen in the following dialogue in the classroom; 


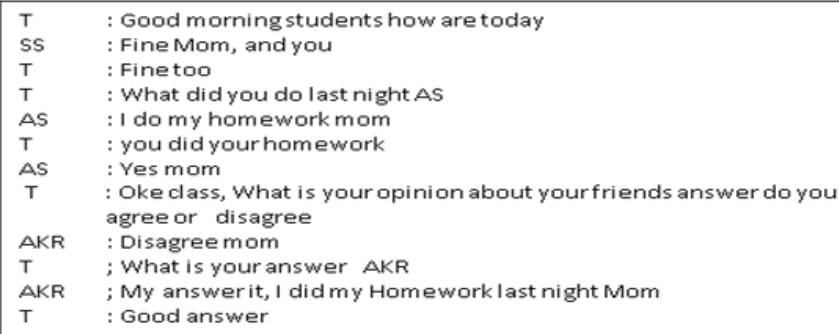

Figure 3.1

The figure 3.1 above showed that, one of the teachers wanted to recheck the students' linguistic aspects and she saw some mistakes which have been made by one of the students. The way she used to correct the students' answer is by asking the other students opinion related to their classmate answers'(AS). This way she used to activate students' intuitive heuristic in learning to check their mistakes in grammatical form..

The next activity that the teachers used to facilitate the students' grammar skill was by explaining the linguistic feature and the expression about the topic. She gave examples of the sentences then she asked the students to analyze the pattern of the sentence then asked them to make one sentence about uttering the expression by aim to know whether they have already understood the pattern. The next figure tells the detail.

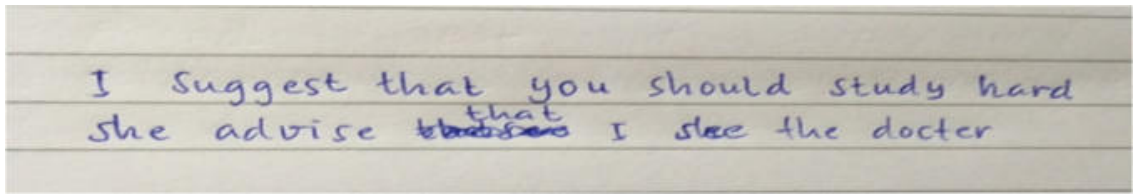

Figure 3.2

The Figure 3.2 above shows that the students got the point from the teacher explanation about the grammar point, thus they can handle the tasks well. The teachers tried to maximize students' learning opportunity and activating their intuitive heuristic, facilitated the improvement of the students' speaking skill especially in grammar aspect. The students speaking progress on grammar point can be seen on the figure above. The detail is the students did not make the mistake no more two errors during the classroom presentation.

\subsubsection{Vocabulary}

The second component of speaking skill is mastery vocabulary. The following explains the activities that the teachers provided to facilitate students' vocabulary ability. One of the teachers requested the students to look at the textbook on page 19 asked them to read loudly. It was continued by reading the conversation and translating together. The detail data can be seen on Appendix 8 data 8 . The translation process was by letting the students to check dictionary, asking to friends, or teacher answer. This activities describe the implementation of the skills that integrated in reading, speaking and one of the language component is vocabulary aspect. By conducting this activity, students learnt how to express the transactional interaction in written and spoken.

The integration of the language skills was continued when the teacher asked the students to write a paragraph consisted of their opinion and thought about the problem given in the task with their partner, because to get the answer of the problem they should discuss it with their partner. They wrote their result of discussion in a piece of paper and submitted to the teacher. The students accepted a learning experience, which was integrated to their language skills, vocabulary and writing. The next figure shows the result of students' writing.

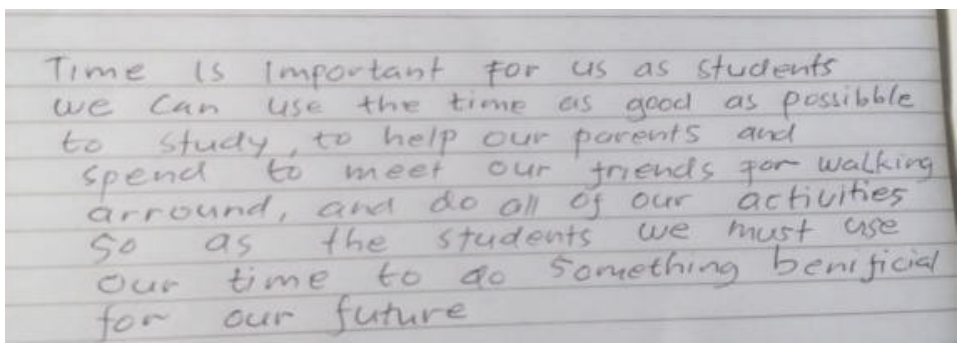

Figure 3.3 Students' writing paragraph 
From Figure 3.3 above, it can be said that the teachers' strategy that facilitated the students' vocabulary was integrated in language skills strategy that can help students to improve the their target language competence. Students progress in vocabulary aspect can be read on their result of writing a paragraph because they can use the appropriate words/ phrase to convey the information orally and written form, thus it can be said that the students have increased their vocabulary aspect in order to improve the students writing skill

\subsubsection{Fluency}

The next components of speaking was fluency. The following explanation show the way how the implementation of the teachers' strategy facilitated the students' speaking skill especially in fluency aspect. The teacher asked one of the students came in front of the class and told about her experience, when she was attended on her friend's birthday party. The Excerpt below explains the students story.

Rina : Well friends ......mmm I want to tell about ...mmm the celebration
of Ima's birthday last night. I go there with my ......emmm young
sister. ...eee when we arrived at Ima's house, ...eee her mother ask me to
sing Ima's .ee favorite song. The title of the song is Mother how are you
today but ...eee I ashamed to sing he he. Thank you.

Figure 3.4

From the Excerpt above, It can be said that the teacher tried to facilitate the students' opportunity to improve their fluency ability. Although, there was only one mistake they have made, but the teacher did not complain. The wrong sentence of the story was "I go there with my young sister". The sentence should be"I went there with my young sister". This is one way to encourage the students to take a part actively and use the language to communicate. Not always pointed out on students mistake. It will make the students de-motivated to speak out in order to improve their speaking skill. And the student has made so many pauses she can handle the task well.

From the explanation above it can be seen that the teachers' strategy that facilitated the students' speaking skill especially in the aspect of fluency is maximizing learning opportunity strategy. This strategy ask the teachers should have the competence to design activities that should involve the students to be active during teaching and learning process. This is the simple way to train the students to improve their fluency in speaking skill. During teaching and learning process the students can transmit the information fluently enough and can be perceptibly by the other people.

\subsubsection{Students Engagement}

Tabel 3.2 Cognitive Aspect

\begin{tabular}{|c|c|c|c|c|c|}
\hline \multirow[t]{2}{*}{$\mathbf{A}$} & \multirow{2}{*}{$\begin{array}{l}\text { Cognitive Engagement } \\
\text { Comprehension } \\
\end{array}$} & \multicolumn{2}{|c|}{ School A } & \multicolumn{2}{|c|}{ School B } \\
\hline & & Yes & No & Yes & No \\
\hline A1 & $\begin{array}{l}\text { Answering the teachers' questions, } \\
\text { when teacher wants to know students' } \\
\text { understanding about the material } \\
\text { recently presented }\end{array}$ & 19 & 8 & 22 & 5 \\
\hline
\end{tabular}

From cognitive engagement above it can be said that school A and school B can answer the teacher's questions and understand the material. The percentage of school B was a bit higher than those of the percentage of school A. The other indicator in cognitive engagement was sharing the ideas. It will be explained in the next following table: 
Table 3.3 Cognitive Aspect

\begin{tabular}{llllll}
\hline & Cognitive Engagement & School A & School B \\
\hline S2 & Share Idea & Yes & No & Yes & No \\
\hline $\begin{array}{l}\text { Students in group or in pairs to share the } \\
\text { information or sharing ideas to complete that tasks } \\
\text { given }\end{array}$ & & & 25 & - \\
\hline
\end{tabular}

From Table 3.3 on share ideas the indicator of observation and interview showed that $100 \%$ of the students in school A or School B agreed that the teacher divided them into group or pairs that can help them to finish their tasks given. Teacher in school A and School B.

Meanwhile, there are two indicators of Emotional engagement: Interest, and worried. In interest facets, data observation shows that $88 \%$ (20) students could respond and they participated actively in classroom activities. This data were supported by the result of interview, which showed that the students could take a part in the classroom activities, it can be seen in the following table.

Table 3.4 Emotional Engagement

\begin{tabular}{|c|c|c|c|c|c|}
\hline \multirow[t]{2}{*}{ B } & \multirow{2}{*}{$\begin{array}{l}\text { Emotional Engagement } \\
\text { Interest }\end{array}$} & \multirow{2}{*}{$\begin{array}{l}\text { School A } \\
\text { Yes }\end{array}$} & \multicolumn{3}{|c|}{ School B } \\
\hline & & & No & Yes & No \\
\hline \multirow[t]{2}{*}{ B1 } & Preferences in English class activities & 20 & 7 & 21 & 5 \\
\hline & Worried Indicator & & & & \\
\hline B2 & $\begin{array}{l}\text { Afraid to make mistake when communicate with the teacher } \\
\text { or with classmate }\end{array}$ & 25 & - & 25 & - \\
\hline
\end{tabular}

From the Table 3.4 the interest indicator, it can be obtained that $80 \%(20)$ of the students in school A, while, $84 \%$ (21) of the students of school B participated actively in the class, because the teachers were not monotonous in presenting the materials in the class that can be seen in supporting interview data on the table above.

On worried indicator, it is found that there are $100 \%(25)$ of the students in school A and school B could speak but in short sentences. This data were supported by the result of interview, it can be found that, the students had enthusiasm to study English, but sometimes, they were afraid to make mistake when they tried to communicate with teacher or the classmate. The detail can be seen on the table 4.16 above. From the data above, it can be said that the teachers' role is really needed to encourage them to speak in order to improve their speaking skill.

Behavioral engagement has several numbers of indicators. They are Attention, Effort, Classroom Participation, being on time to follow the Lesson. From wholly observation from attention indicator in school A and school B, there were $100 \%$ of the students followed the teachers' instruction to do the tasks and paid attention during the learning process. While the same result from, interview from both of the schools can be seen in the table below.

Table 3.5 Attention Indicator

\begin{tabular}{llllll}
\hline C & Behavioral Engagement & School A & School B \\
\hline & Attention & Yes & No & Yes & No \\
\hline C1 & $\begin{array}{l}\text { The students always follow the teachers' instruction } \\
\text { during the learning process to do tasks }\end{array}$ & 25 & - & 25 & - \\
\hline C2 & $\begin{array}{l}\text { The students always pay attention to teacher during } \\
\text { teaching and learning process }\end{array}$ & 25 & - & 25 & - \\
\hline
\end{tabular}

From Table 3.5 dealing with the effort indicator the result of observation shows that school A, there were $100 \%$ (25) students could handle the tasks both in as well as out of the classroom and submit it to the teachers. In school B there were $96 \%$ or 24 students could do the same thing. Furthermore, supporting data from result of interview showed that the students had the responsibility to achieve the learning result optimally. The detail can be seen in the Effort table below: 


\begin{tabular}{llllll}
\hline \multicolumn{7}{c}{ Table 3.6 Effort } & & \\
\hline C & Behavioral Engagement & School A & School B \\
\hline & Effort & Yes & No & Yes & No \\
\hline C3 & $\begin{array}{l}\text { The students do the tasks in or out of the } \\
\text { class given by the teacher, and collected } \\
\text { according to the teachers' deadline }\end{array}$ & 22 & 3 & 24 & 1 \\
\hline
\end{tabular}

From Table 3.6 Classroom Participation, the result of observation showed that in school A there were $76 \%$ or 22 students participated actively and asked questions if the information from the teachers is not clear. In school B there were $80 \%$ or 24 students could do the same action. The supporting data from interview showed that School A and School B had the same attitude during the learning process in the class. The detail can be seen in the following table.

Table 3.7 Student Participation

\begin{tabular}{llllll}
\hline C & Behavioral Engagement & School A & \multicolumn{2}{c}{ School B } \\
\hline & Students Participation & Yes & No & Yes & No \\
\hline C4 & $\begin{array}{l}\text { Taking part actively in the class and asking } \\
\text { the question if the teachers' information } \\
\text { unclear }\end{array}$ & 17 & 3 & 18 & 4 \\
\hline
\end{tabular}

On the next indicator the students had responsibility to follow the lesson and they were always on time. The observation result showed that in school A there were $68 \%$ or 17 students and in school B there were $72 \%$ or 18 students had the same attitude during the learning process. In teaching learning process, students sometimes asked for being out of the class with various reason. But most of them stayed in class until the end. The detail can be seen in the students' participation below.

Table 3.8 Being on time

\begin{tabular}{lllllll}
\hline C & Behavioral Engagement & School & \multicolumn{2}{c}{ School B } \\
\hline & Being on Time to Follow the Lesson & Yes & No & Yes & No \\
\hline C5 & On time to follow the English lesson & 22 & 3 & 24 & 1 \\
\hline
\end{tabular}

It signifies the consistency of students engagement need to be a noteworthy consideration by the teachers, because it is also sustaining factor to gain the objective of learning. In addition, the comparison between both of schools provides obvious outcome. The average number of students' participation in school B to overall sub-indicators is higher than those of the school A. It indicates that students engagement concept facilitated by teacher of school B to improve students' speaking skill is more successful in the aspect of implementation.

The most engagement aspect that appeared in the implementation of the students' teaching strategy was the behavioral aspects. It is better than those of the two others aspect such as cognitive and emotional. It can be said the behavioral aspect was facilitated more by the implementation of the teachers' macro strategies in facilitating students speaking skill. The behavioral aspect cover three components: effort, students participation, and being on time. Effort, is a part of students engagement which help them to improve their act to do the tasks, because if they have good effort, they can gain the their learning objective during the learning process, they will understand how to perform maximally to do the tasks.

The next Component is students participate. Students participate is student engagement to encourage them to take a part actively to do all of the tasks during the learning process. They have the good responsibility in finishing all of their tasks. 
The last one is being on the time. This component is shows the students responsibility to follow the lesson in the class, and can help them to track the teacher explanation about the material from the beginning until the end of the lesson. In the other word it can be said that, the students were more attentive to the lesson, more active in the class and more discipline.

\section{Result and Discussion}

Students Engagement cover three components; Cognitive, Emotional, and Behavioral engagement. Each component has more than one aspects to be assessed. It was prominent than those of the two others aspect such as cognitive and emotional. It is in line with Paris"s (2003) study, which found that there is relation between engagement and school related outcome. The result of the study showed that the positive correlation between behavioral engagement and speaking achievement. The students were more attentive to the lesson, more active in the class and more discipline. In general, it can be said that students' engagement had closed relationship with the students' academic achievement. Mai,Yusuf, \& Saleh (2015) stated that there is relationship between students' motivation and engagement on their academic satisfactory. The result showed that students that have a good level of motivation and level of engagement have a satisfying achievement. In addition, Gunic (2015) also found that there is significant relationship between students engagement and academic achievement especially in the dimensions of cognitive behavioral engagement and sense belonging. However, Jonas (2016) found that students' engagement is passively associated with academic achievement.

It can be summarized from the explanations above that students behavioral engagement dominantly in promoting students speaking practice better than those of the other two kinds of students' engagement, cognitive and emotional engagement. Behavioral engagement is one of the important points that should be considered by the teachers. Students' behavioral engagement can be built through productive classroom activities and good interaction between teacher-students and students-students interaction.

As it already clarified in point 1 about the existence of teacher attention in the class, teacher should realize that their sincere attention to students gives deep impact so that can change the students unconsciously. Attention is an action that is done by the teacher to the students by aimed to give motivation to lead the students to be better personally and academically.

Students will show better process in learning as they are already being an autonomous learner. When the students are in this phase, it means they realize that they need the knowledge, need the practice because they realized that they have purpose in learning something. Thus, they change themselves into better learner and be more active in the class, because they know that to be like this means they will be success in something they learn.

\section{Conclusion and Suggestion}

\section{A. Conclusion}

Good speaking skills are needed by the students as it is known that English becomes an International language. English also lead the students to have more quality knowledge as the references are mostly in English. Moreover, economical structure has high demand on English. Thus, teacher should enhance students to have good will in learning English. Speaking class with variety activities are needed to provide students different and challenging experience in learning.

Teachers who stimulate students with varied activities in speaking class mean they give the students opportunity in learning. Engagement is needed to create students who do not only have good will but also have good behavior in learning English and have good mind set in seeing English as a daily need in the global worldwide.

This study proven that activities in speaking class are admitted able to enhance the students better in practicing speaking. Students also are motivated in learning and put the best effort in trying to speak up. They have good motivation and more aware of the need of English not only for academic but also for their live.

Their effort shows their participation in the class are increase and the students try to not come late and limited their selves in making such behavioral mistakes that influence their learning, such as not doing homework or coming late to the class. They also have courage to practice speaking with other students and teachers outside the class, moreover their attitude in learning English is getting more responsible. They became more active to take part to all activities in the classroom. 
Moreover, the students' attention, effort, participations, and discipline in following the teaching learning process become important factors that should be noticed by the teachers in developing the students' speaking skill, since based on the results the teachers' strategy enhance more on the students' behaviour engagement than those of the two others aspects of students' engagement, cognitive and emotional engagement. Therefore, the teachers' teaching strategies functions do not only facilitate the students to understand the materials but they also encourage students to get involve in the class through the engagement strategies. And the other aspect is the teachers also can encourage the students' engagement on the teaching learning process by giving attention and reinforcement during teaching and learning process

Finally I would to thank (1) Directorate General of Higher Education Ministry of Research, Technology, and Higher Education of Republic of Indonesia which funded this research, (2) The principle of SMA Negeri I Ambon and SMA Negeri Siwalima Ambon, who have given permission to conduct the research in their institution that they lead. (3) teachers and students who were participated in finishing this study

\section{B. Suggestion}

Expectantly, further research will be more focus on the students' behavioral engagement because it can be parameter in measuring the successful. As behavior can be used to prove somebody emotional and mind.

\section{References}

Anjaniputra, A. G. (2013). “Teacher's Strategies in Teaching Speaking to Students at Secondary Level”. Journal of English and Education.vol. 1 No. 12. pp. 1-8.

Brewster, C. \&Fager, J. (2000). Increasing Students Engagement and Motivation: From Time-to time to Homework. Northwest Regional Educational Laboratory. https://www.amle.org/BrowsebyTopic/W.http:www.ktiguru.org/index.php/profesiguru.http://regional.k ompas.com/1015.

Brown, H. D. (2001). Teaching by Principles: An Interaction Approach to language Pedagogy.San-Fransisco: longman.

Brown, H. D. (2007). Principles of Language Learning and Teaching fifth edition.San Francisco State University. Brown, H. D. and Yule, G. (2010). Teaching the Spoken Language. Cambridge University Press

Bryson, C. and Hand, L. (2007). "The Role of Engagement in Inspiring Teaching and Learning:Innovation in Education and Teaching”. International Journal. Vol.44.No. 4. pp. 349-362.

Cresswell, .J. W. (2008).Educational Research.University of Nebraska- Lincoln.

Departement Pendidikan Nasional Republik Indonesia. (2006). Pedoman Kurikulum Tingkat Satuan Pendidikan untuk Sekolah Menengah Atas Tahun 2006. Jakarta. Depdiknas

Fredricks, J. A. Blumenfeld, P. C. and Paris, A. H. (2004). "School Engagement: Potential of the Concept, State of the Evidence Review of Educational Research". Educational Journal. Vol.74. No. pp. 59-109.

Harper,S.R. andQuaye,S.J.(2009). Student Engagement in Higher Education. New Yorkand London: Rutledge

Kuh, G.D. (2003). What we're learning about student engagement from NSSE. Change, 35(2), 24-32.

Krause, K. and Coates, H. (2008). "Students' Engagement in First-Year University Assessment and Evaluation in Higher Education". Educational Journal.Vol. 33.No.5. pp. 493-505.

Khameis, M. (2006). Using Creative Strategies to Promote Students'Speaking Skills. Education Degree From Fujairah Woman's College.

Lam, S.F., Jimerson, S., Kikas, E., Cefai, C., Veiga, F.H., Nelson, B. and Zollneritsch, J. (2012). "Do Girls and Boys Perceive Themselves as Equally Engaged in School"? The Results of an International Study from 12 Countries.Journal of School Psychology, Vol. 50.No.5.pp.77-94. 